\title{
Corrigendum: Production of Ins(1,3,4,5)P4 mediated by the kinase Itpkb inhibits store-operated calcium channels and regulates $B$ cell selection and activation
}

Andrew T Miller, Mark Sandberg, Yina H Huang, Michael Young, Susan Sutton, Karsten Sauer \& Michael P Cooke

Nat. Immunol. 8, 514-521 (2007); published online 8 April 2007; corrected after print 24 May 2007

In the version of this article initially published, two labels in the key to Figure $6 c$ are reversed. The blue line is "Ins $(1,3,4,5) \mathrm{P} 4(300 \mu \mathrm{M})$ " and the

Corrigendum: Toll-like receptor 9-dependent activation by DNA-containing immune complexes is mediated by HMGB1 and RAGE

Jane Tian, Ana Maria Avalos, Su-Yau Mao, Bo Chen, Kannaki Senthil, Herren Wu, Peggy Parroche, Stacey Drabic, Douglas Golenbock, Cherilyn Sirois, Jing Hua, Ling Ling An, Laurent Audoly, Greg La Rosa, Angelika Bierhaus, Peter Naworth, Ann Marshak-Rothstein,

Mary K Crow, Katherine A Fitzgerald, Eicke Latz, Peter A Kiener \& Anthony J Coyle

Nat. Immunol. 8, 487-496 (2007); published online 8 April 2007; corrected after print 24 May 2007

In the version of this article initially published, the legends for Figures $\mathbf{3} \mathbf{c}$ and $\mathbf{5 b}$ fail to indicate that portions of these are the same experiments as in Figures $\mathbf{3 b}$ and 5a, respectively. The correct legends state "Binding with or without CpG-A is from the same experiment as in b" (for Fig. 3c) and "Data for PL2-3 in the presence of supernatant alone (bold lines) as detected by anti-IgG2a (left, a,b) and by anti-HMGB1 (right, a,b) are from the same experiment" (for Fig. 5b). Also, error bars are missing from Figure 3c. The errors have been corrected in the HTML and PDF versions of the article.
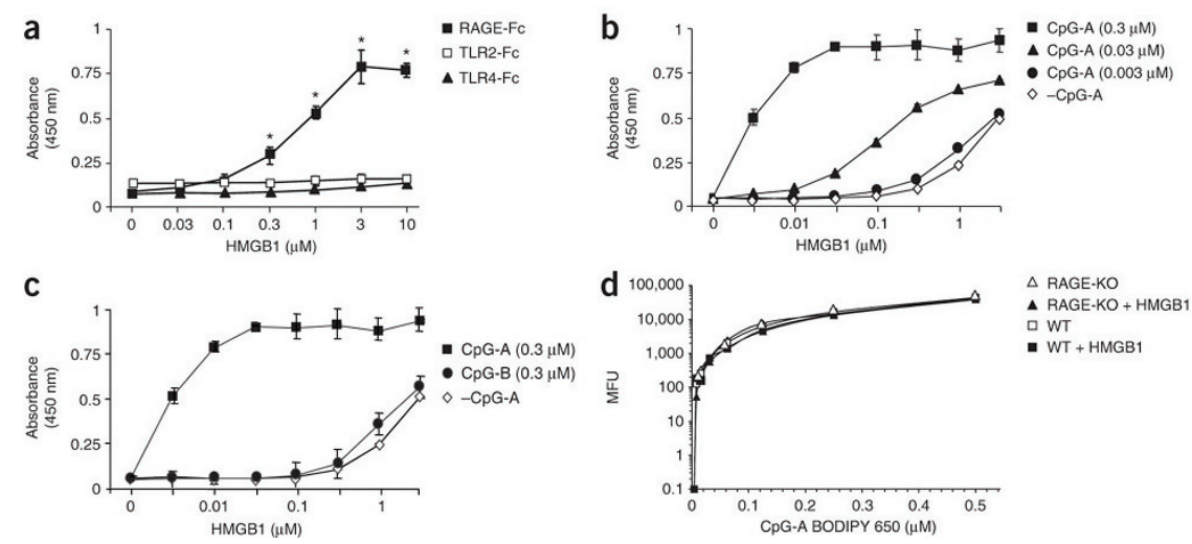

\section{Erratum: Local increase in thymic stomal lymphopoietin induces systemic alterations in B cell development}

Alexander Astrakhan, Miyuki Omori, Thuc Nguyen, Shirly Becker-Herman, Masanori Iseki, Theingi Aye, Kelly Hudkins, James Dooley, Andrew Farr, Charles E Alpers, Steven F Ziegler \& David J Rawlings

Nat. Immunol. 8, 522-531 (2007); published online 1 April 2007; corrected after print 30 May 2007

In the version of this article initially published, the second subheading on page 523 is incorrect. The correct subheading should be TSLP stimulates the population expansion of late pro-B cells. The error has been corrected in the HTML and PDF versions of the article. 